\title{
Erratum to: Testing the influence of sediment granulometry on heterotrophic respiration with a new laboratory flow-through system
}

\author{
Nataša Mori $^{1}$ • Barbara Debeljak ${ }^{1} \cdot$ David Kocman $^{2} \cdot$ Tatjana Simčič $^{1}$
}

Published online: 7 June 2017

(C) The Author(s) 2017. This article is an open access publication

\section{Erratum to: J Soils Sediments}

\section{DOI 10.1007/s11368-016-1613-0}

The article "Testing the influence of sediment granulometry on heterotrophic respiration with a new laboratory flowthrough system", written by Nataša Mori, Barbara Debeljak, David Kocman, and Tatjana Simčič, was originally published electronically on the publisher's internet portal (currently SpringerLink) on 29 November 2016 without open access.

With the author(s)' decision to opt for Open Choice the copyright of the article changed on 6th June 2017 to $($ ) The Author(s) 2017 and the article is forthwith distributed under the terms of the Creative Commons Attribution 4.0 International License (http://creativecommons.org/licenses/by/4.0/), which permits use, duplication, adaptation, distribution and reproduction in any medium or format, as long as you give appropriate credit to the original author(s) and the source, provide a link to the Creative Commons license, and indicate if changes were made. The original article has been corrected.

Open Access This article is distributed under the terms of the Creative Commons Attribution 4.0 International License (http:// creativecommons.org/licenses/by/4.0/), which permits unrestricted use, distribution, and reproduction in any medium, provided you give appropriate credit to the original author(s) and the source, provide a link to the Creative Commons license, and indicate if changes were made.

The online version of the original article can be found at http://dx.doi.org/ 10.1007/s11368-016-1613-0

Nataša Mori

natasa.mori@nib.si National Institute of Biology, Večna pot 111, 1000 Ljubljana, Slovenia

2 Institute Jožef Stefan, Jamova 39, 1000 Ljubljana, Slovenia 